\title{
The impact of climate warming on the phenology of ground beetles in the Northern Baikal region ${ }^{+}$
}

\author{
Tatiana Ananina ${ }^{1,2}$, Alexander Ananin ${ }^{1,2}$ and Irina Aiurzanaeva ${ }^{1, *}$ \\ 1 Federal State Establishment “United Administration of Barguzinsky State Nature Biosphere Reserve and \\ Zabaikalsky National Park"; t.l.ananina@mail.ru \\ 2 Institute of General and Experimental Biology SB RAS; a_ananin@mail.ru \\ * Correspondence: aurzanaeva@gmail.com, +7(983)3320261, Komsomolskaya str. 44-64, Ulan-Ude 670045, \\ Russia, 15-06-2021 \\ + Presented at the 1st International Electronic Conference on Entomology (IECE 2021), 1-15 July 2021; \\ Available online: https://iece.sciforum.net/.
}

Citation: Ananina, T.; Alexander Ananin; A. and Aiurzanaeva, I. The impact of climate warming on the phenology of ground beetles in the Northern Baikal region, in Proceedings of the 1st International Electronic Conference on Entomology, 1-15 July 2021, MDPI: Basel, Switzerland, doi:10.3390/IECE-10413

Published: 30 June 2021

Publisher's Note: MDPI stays neutral with regard to jurisdictional claims in published maps and institutional affiliations.

Copyright: (C) 2021by the authors. Submitted for possible open access publication under the terms and conditions of the Creative Commons Attribution (CC BY) license (http://creativecommons.org/licenses /by/4.0/).

\begin{abstract}
Changes in environmental factors affect natural phenological patterns. In the Northern Baikal region, the main drivers of climate change are air temperatures. Average annual air temperatures for the study period 2005-2020 increased by $0.4{ }^{\circ} \mathrm{C}$, while the level of atmospheric precipitation remained the same. Changes in the temperature regime led to shifts in the phenological seasons of the year. The beginning of the spring-summer season began to outpace the average long-term dates, and the onset of the autumn-winter seasons began to lag behind. The biological summer has increased by 7-8 days. Phenological shifts in the calendar seasons of the year affect the vital processes of ectothermic plant and animal species. The kinetics of phenological shifts has been studied. Using the example of the dominant species of ground beetles of the Barguzinsky Reserve, we present a method for determining the rate and direction of phenological shifts in the stages of seasonal activity.
\end{abstract}

Keywords: Northern Baikal, Barguzinsky Reserve, air temperature, phenological season, phenological shift.

\section{Introduction}

Ground beetles are a generally recognized model and indicator object of research in various ecological studies [1-3]. The impact of weather on ground beetles is very significant in the continental conditions of the Northern Baikal region with short summers and long winters The objectives of the study included: identification and assessment of the phenological shift in the seasonal activity of model species of ground beetles inhabiting the shores of Lake Baikal. Ground beetles were monitored on the territory of the Barguzin State Natural Biosphere Reserve on permanent test areas [4]. The reserve is located on the western macroscope of the ridge of the same name. The climatic conditions of the study area are determined, first of all, by its geographical position within the continent and its location on the shores of Lake Baikal. The average annual amplitude of air temperature is $23.5^{\circ} \mathrm{C}$. Annual precipitation is $400-600 \mathrm{~mm}$. In the warm season, more precipitation falls, in the cold $-100-300 \mathrm{~mm}$. The temperature regime is largely influenced by the cold winter period of the year, which lasts 13 decades in Northern Baikal, in contrast to the warm summer season - only 9 decades. Spring on Northern Baikal is protracted -9 decades, in contrast to the short autumn season -5 decades [5].

\section{Materials and Methods}

The entomological plots are in the shore of lake Baikal (Figure 1). 


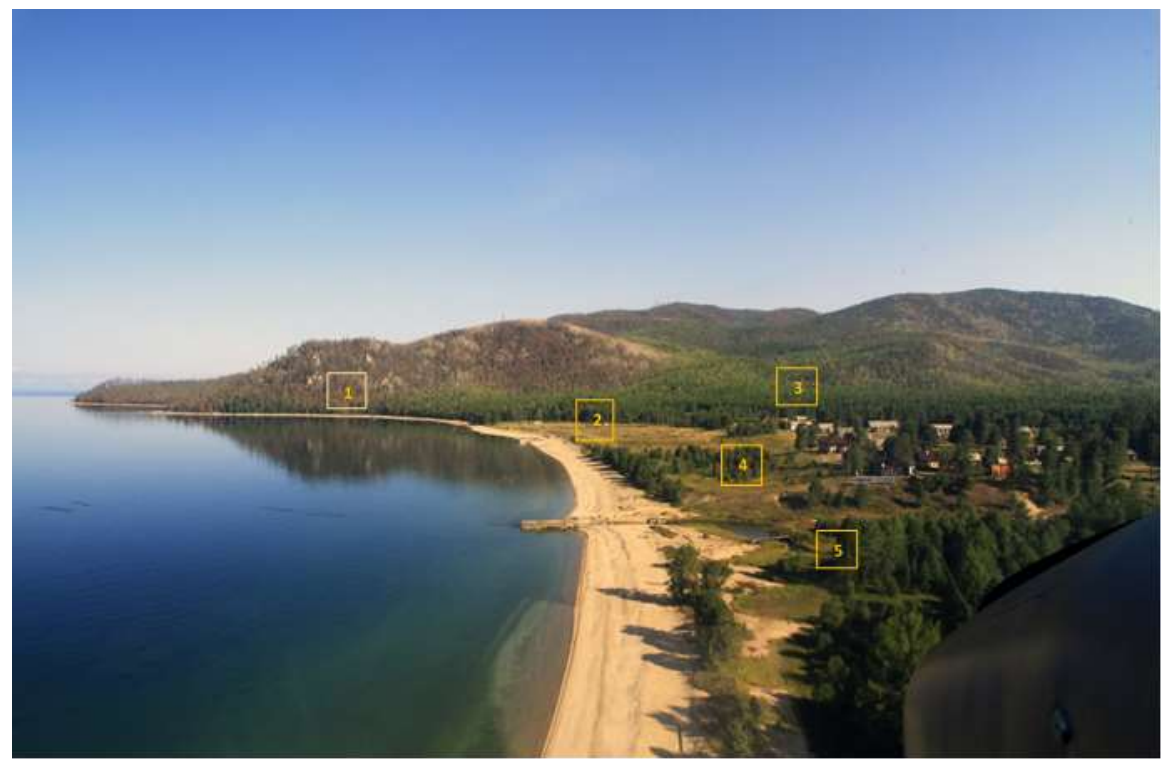

Figure 1. The location of entomological plots on Baikal terraces in Davsha Bay

Biotope designations: Blueberry cedar, plot 1; Forbs meadow, plot 2; Pine-birch forest, plot 3; Bushy meadow, plot 4; Larch-pine forest, plot 5.

The temperature of the surface air layer at permanent plots was recorded during the period of activity of ground beetles from the first decade of May to the third decade of September by using weekly thermographs and automatic thermochrones. Thermal mode on the forbs meadow, plot 2 was not measured.

When studying phenological shifts, it is important to study the dynamics of the dates of the onset of phenological seasons, which carry an indicator value in the periodization of the annual cycle. The names of seasons and temperature limits was chosen according to the section "Nature Calendar" from the multivolume publication "Chronicle of the Nature of the Barguzinsky Reserve". The boundaries of phenological seasons in the description of phenological phenomena of the Barguzinsky Reserve: "empty spring" (final transition at max $t>5^{\circ}$ ), "green spring" (final transition at max $t>10^{\circ}$ ), "pre-summer" (first transition min $t>5^{\circ}$ ), "complete summer "(stable transition min $t>5^{\circ}$ ), " early autumn "(first frost)," golden autumn "(transition $\left.\min t<0^{0}\right)[6]$.

Ground beetles were caught by the Barber pitfall trap method with modifications [7]. Traps (half-liter glass jars filled one third with a $4 \%$ formalin solution) were dug in in groups of 5 in one line at a distance of $5 \mathrm{~m}$ from each other. Samples were collected every ten days during the entire vegetation period (from May to September). The established catching regime is most indicative for studying the seasonal activity of ground beetles in the weather conditions of the Northern Baikal region. The dominant species of ground beetles, which have more than $10 \%$ of the total species abundance of the population in the biotope, were chosen as model ones: Pterostichus dilutipes Motsch., 1844, Pterostichus montanus Motsch., 1844, Pterostichus eximius Mor., 1862, Pterostichus nigrita Payk., 1790, Harpalus rufipes De Geer, 1774, Calathus micropterusDuft., 1812, Carabus odoratus barguzinicus Shil., 1996.

To clarify the kinetics of phenological shifts, the beginning and end of the activity period of ground beetles, a regression analysis of long-term series was carried out. The phenological shift was determined by the equation of linear trends $[8,9]$ :

$$
y=\alpha b+c,
$$

$\alpha$ - the quantitative value of the phenological shift in one year. Direction of the series by the sign of the formula:

leading "+" and lagging "-". 
For ease of use, the obtained value of the phenological shift $\alpha$ was multiplied by 10 . Statistical processing of the material was carried out according to the generally accepted method with using the Microsoft Excel and Statistics 6.0 packages.

\section{Results}

The composition of vegetation, exposition and the illumination of a habitat in Northern Baikal region are the main parameters that determine its heat supply. In our study, the warmest biotopes are the open and illuminated meadows on the second Baikal terrace and the Pine-birch forest on the third terrace.The coldest biotopes are the shaded Cedar forest on the second terrace and the Larch-pine forest on the first terrace [10]. For example, the difference in minimum temperatures for the vegetation season in the Pine-birch and Larch-pine forest between the third and first terraces reaches $4,5^{\circ}$ (Table 1 ).

Table 1. Temperature decadal characteristics of biotopes during the vegetative period 2005-2020

\begin{tabular}{ccccc}
\hline $\mathbf{t}^{\circ} \mathrm{C} /$ № plot & $\mathbf{1}$ & $\mathbf{3}$ & $\mathbf{4}$ & $\mathbf{5}$ \\
\hline Mid $\mathrm{t}^{\circ} \mathrm{C}(\mathrm{V}-2-\mathrm{X}-1)$ & $+11,4$ & $+11,9$ & $+12,0$ & 9,7 \\
\hline Max $\mathrm{t}^{\circ} \mathrm{C}(\mathrm{V}-2-\mathrm{X}-1)$ & $+24,6$ & $+25,1$ & $+27,9$ & 23,6 \\
\hline Min $\mathrm{t}^{\circ} \mathrm{C}(\mathrm{V}-2-\mathrm{X}-1)$ & $-6,2$ & $-3,8$ & $-5,3$ & $-8,3$ \\
\hline Min $\mathrm{t}^{\circ} \mathrm{C}(\mathrm{V}-2)$ & $-2,0$ & $-0,4$ & $-1,5$ & $-3,8$ \\
\hline Min $\mathrm{t}^{\circ} \mathrm{C}(\mathrm{V}-3)$ & $+0,7$ & $+1,7$ & $+0,3$ & $-2,0$ \\
\hline Min $\mathrm{t}^{\circ} \mathrm{C}(\mathrm{VI}-1)$ & $+2,4$ & $+3,3$ & $+2,2$ & 0,0 \\
\hline Min $\mathrm{t}^{\circ} \mathrm{C}(\mathrm{VI}-2)$ & $+5,4$ & $+6,1$ & $+4,7$ & $+2,5$ \\
\hline Min $\mathrm{t}^{\circ} \mathrm{C}(\mathrm{VI}-3)$ & $+6,7$ & $+7,3$ & $+5,9$ & $+3,7$ \\
\hline Min $\mathrm{t}^{\circ} \mathrm{C}(\mathrm{IX}-1)$ & $+5,6$ & $+4,6$ & $+4,3$ & $+2,9$ \\
\hline
\end{tabular}

The start of the spring-summer phenological seasons: Empty spring, Green spring, Pre-summer and Full summer go ahead of the average long-term dates, and delays the onset of the phenological autumn seasons: Early autumn and Golden autumn (Table 2).

Table 2. Average long-term characteristics of phenological seasons in the warm season in the Northern Baikal region.

\begin{tabular}{cccc}
\hline Phenological season & 1955-2019 & 2005-2020 & $\begin{array}{c}\text { Phenological shifts } \\
\text { (days) }\end{array}$ \\
\hline Empty spring & 6.05 & 1.05 & 5 \\
\hline Green spring & 26.05 & 20.05 & 6 \\
\hline Pre-summer & 14.06 & 8.08 & 6 \\
\hline Full summer & 5.07 & 28.06 & 5 \\
\hline Early autumn & 1.09 & 4.09 & 3 \\
\hline Golden autumn & 18.09 & 21.09 & 3 \\
\hline
\end{tabular}

An important property of biota is its ability to respond to changes in external environmental factors, primarily to variations in air temperature, and adapt to these changes. According to Table 2, the onset of the phenological seasons Empty spring and Full summer is ahead of the average long-term dates by 5 days, Green spring and Preletye - by 6 days, and delays the arrival of the phenological seasons Early and Golden autumn by 3 days. Air temperatures act as triggers of the initial and final stages of the period of ground beetles activity. Ectothermic animal species, including ground beetles, show a plastic reaction to climate fluctuations $[11,12,13,14,15]$.In response to an increase in temperature in the spring-summer-autumn season, ground beetles respond with an early coming out to the surface and a late going into diapause. The duration of the active period of ground beetles is lengthening (Table 3). 
Table 3. Dates of the initial and final periods of seasonal activity, and phenological shifts in the dominant species of ground beetles.

\begin{tabular}{ccccccccc}
\hline $\begin{array}{c}\text { Species, } \\
\text { № plot }\end{array}$ & \multicolumn{4}{c}{ Active period start date } & \multicolumn{3}{c}{ End of the active period } \\
\cline { 2 - 8 } & Mid. & Max. & Min. & $\begin{array}{c}\text { Pheno } \\
\text { shift }\end{array}$ & Mid. & Max. & Min. $\begin{array}{c}\text { Pheno } \\
\text { shift }\end{array}$ \\
\hline Pt.montanus, 3 & 5.6 & 22.6 & 14.5 & 8 & 27.8 & 20.9 & 25.7 & 20 \\
\hline C. odoratus, 1 & 16.6 & 5.7 & 5.6 & 3 & 17.8 & 15.9 & 15.7 & 28 \\
\hline Cal.micropterus, 3 & 10.6 & 25.6 & 25.5 & 8 & 25.8 & 30.9 & 5.8 & - \\
\hline Pt. dilutipes, 4 & 11.6 & 25.6 & 15.5 & - & 4.9 & 30.9 & 19.8 & 12 \\
\hline Pt. eximius, 4 & 27.5 & 20.6 & 14.5 & 4 & 30.8 & 30.9 & 5.8 & 15 \\
\hline Pt. nigrita, pl.2 & 14.6 & 10.7 & 25.5 & 10 & 10.8 & 15.9 & 25.7 & 16 \\
\hline H. rufipes, pl.2 & 14.6 & 1.7 & 25.5 & 17 & 22.8 & 31.8 & 15.8 & -
\end{tabular}

In all model species of ground beetles, to a greater or lesser extent, phenological shifts in seasonal activity are recorded.The response of ground beetle species to phenological shifts in the spring-summer and autumn seasons is ambiguous. The onset or the end of activity is ahead of the long-term mean values or is unchanged. The onset in Pt. montanus, Cal. micropterus, C. odoratus, Pt. eximius, Pt. nigrita, H. rufipes and remains unchanged in Pt. dilutipes. The end of the period of activity is delayed in Pt. montanus, C. odoratus, Pt. dilutipes, Pt. eximius is ahead of the long-term mean values. The period of seasonal activity in Cal. micropterus and H. rufipes ends at the same time (Table 3).

\section{Conclusion}

In the Northern Baikal region, as a result of climate warming, a shift in the springsummer and autumn phenological seasons of the year is recorded. The rate of shift of phenological seasons has drasticallyaccelerated over the past decades. This fact affects the vital activity of ground beetles, causing significant phenological shifts in some species and an extension of the period of seasonal activity. The spring-summer phenological shift is larger in size than the autumn one. Analysis of the reaction of carabid species to an increase in temperature and phenological shifts did not show a negative impact on their vital activity.

Author Contributions: The conceptualization of the research was suggested by Ananina T.L. The collection of ground beetles was carried out by Ananina T.1. and Ananin A.A. The software was used by Aiurzanaeva I.A. The verification and identification of species were carried out by V. G. Shilenkov (National State University, Irkutsk), Koval A.G. (All-Russian Institute for Plant Protection, Saint-Petersburg). Writing, reviewing and editing of the article was done by Ananina T. L. Supervision, translation into English and project administration was done by Aiurzanaeva I. A. All authors read the published version of the manuscript and agreed with it.

Institutional Review Board Statement: The study was conducted according to the guidelines of the Declaration of Helsinki, and approved by the Institutional Review Board of Institute of General and Experimental Biology SBRAS, №56, 11.06.2021.

Informed Consent Statement: Not applicable for studies not involving humans.

Acknowledgments: We thank the administration of the Barguzinsky State Reserve for administrative and technical support in data collection. We thank the funders for participation in interpretation of reported research results.

Conflicts of Interest: The authors declare no conflict of interest.

Informed Consent Statement: Informed consent was obtained from all subjects involved in the study. 


\section{References}

1. Parmesan C. Ecological and evolutionary responses to recent climate change. Annu Rev Ecol. Evol. Syst., 2006,Volume 37(1),pp. 637-669. https://doi.org/10.1146/annurev.ecolsys.37.091305.110100

2. Van der Have T.M.,deJongG. Adult size in ectotherms: Temperature effects on growth and differentiation. Theor. Biol., 1996,Volume 183, pp. 329-340.

3. Kiritani K. Predicting impact of global warming on population dynamics and distribution of arthropods in Japan. Population Ecology, 2006,Volume 48(2), pp. 5-12.Author 1, A.B.; Author 2, C. Title of Unpublished Work. Abbreviated Journal Name stage of publication (under review; accepted; in press).

4. Ananina T. L. Temperature factor in the life of the dominant species of ground beetles (Coleoptera, Carabidae) of the Barguzin ridge. Samara scientific journal of Russian Academy of Science, 2010, Volume 12(33), № 1(5), p.1260-1263. [in russian]

5. Ananina T.L., Ananin A. A. Long-term Climatic Changes in the Northeastern Baikal Region (Russia). Journal of Atmospheric Science Research, 2020,Volume 3 (4), pp. 10-15. DOI: https://doi.org/10.30564/jasr.v3i4.2255

6. Filonov K. P. Seasonal development of nature in the Barguzinsky reserve. Natural complex of the North-Eastern Baikal region, Proceedings of the Barguzinsky state reserve, Buryat book publishing, 1978. Ulan-Ude, No. 7, pp. 47-67. [in russian]

7. Barber Y. Traps for cave-inhabiting insects. Elisha Mitchell Sci. Soc., 1931, № 46, pp. 259-256.

8. Korosov A.V. Special methods of biometrics. Tutorial. - Publishing:PetrSU, 2007,363 p. [in russian]

9. Carmel Y., Kent R., Bar-Massada A., Blank L., Liberzon J., Nezer O., Sapir G., Federman R. Trends in ecological research during the last three decades - a systematic review. PLoSOne, 2013. Volume8(4),pp. 1-9. https://doi.org/10.1101/125781

10. Ananina T. L., Kurkina I. I. Influence of soil moisture on the long-term abundance of ground beetles on the coast of the Northeastern Baikal region.The nature of Baikal Siberia.Proceedings of nature reserves and national parks of Baikal Siberia,2017,Volume 2, Publisher: BSC SDRAS, Ulan Ude, pp. 77-85. [in russian]

11. Pozsgai G., Littlewood N.A. Ground beetle (Coleoptera: Carabidae) population declines and phenological changes: is there a connection? Ecol. Indic, 2014,Volume 41,pp.15-24. https://doi.org/10.1016/j.ecolind.2014.01.029

12. Ibáñez I, Primack R.B., Miller-Rushing A.J. et al. Forecasting phenology under global warming. Philos Trans. R. Soc.Lond. Ser. B.Bio.1 Sci., 2010, Volume 365(1555), pp. 3247-3260. https://doi.org/10.1098/rstb.2010.0120

13. Roy D.B., Sparks T.H. Phenology of British butterflies and climate change. Global Change Biology, 2000, Volume 6(2), pp. 407416.

14. Scranton K., Amarasekare P. Predicting phenological shifts in a changing climate. Proc. Natl. Acad. Sci. USA (PNAS), December 12, 2017, Volume 114 (50), pp. 13212-13217.

15. Dell A, Pawar S, Savage V.M. Systematic variation in the temperature dependence of physiological and ecological traits. Proc. Natl. Acad. Sci. USA,2011,Volume 108, pp. 10591-10596. 